\title{
Irish Studies in Spain - 2020
}

\section{María Losada Friend (ed.)}

Copyright (c) 2021 by the authors. This text may be archived and redistributed both in electronic form and in hard copy, provided that the author and journal are properly cited and no fee is charged for access.

\section{Introduction}

María Losada Friend

Alejandro O'Reilly, Inspector General: Poder Militar, Familia y Territorio en el Reinado de Carlos III

Óscar Recio Morales

Marta Ramón García 229

\section{El relato corto: Sean O'Faolain}

Edited by José Francisco Fernández and translated by Leticia de la Paz de Dios

Santiago Rodríguez Guerrero-Strachan

Samuel Beckett en España: A Multifaceted Perspective

José Francisco Fernández (ed.)

Jordi Vilaró .234

\section{Introduction}

We will always remember this year 2020. So much has happened since last March that it seems an impossible and endless task to sum it up in a few paragraphs. We have endured and learned to live with uncertainty holding on to things that can make us stronger and better. Feeling close to Ireland, studying its culture, looking for new angles to understand its new tendencies and applying academic research to reread its history, peoples and development has been a powerful weapon to beat the Corona pandemic. Confined and threatened by the new situation, Spanish scholars have not surrendered and have kept on working enriching, yet one more year, our knowledge about the beautiful Emerald island. 
In January, when the pandemic was still far away from our horizon, President Higgings made a statement of sympathy on the death of Stephen Joyce, grandson of James Joyce and his last living descendant. The President recalled his visit with him to Joyce's grave in Zurich and mentioned Joyce's poem to Lucia ("A Flower given to my daughter"). One stanza seems to acquire even more sense these days: "Rosefrail and fair - yet frailest/ A wonder wild/ In gentle eyes thou veilest/ My blueveined child"). The fragility and beauty of a life that Joyce describes and his desire to make it eternal through poetry becomes meaningful now that we have felt defenceless, vulnerable and mortal. We have witnessed how the pandemic has affected Ireland's life displaying simultaneously expressions of solidarity, endurance and beauty. It has brought together voices that reveal its cultural diversity and richness and makes us eager to keep tracing the grandeur of their powerful expressions. Thus, Irish writers' opinions spread helpfully in the news, as we read in The Irish Times John Boyne's view about the changes of social media and "the ways in which people use the platform to help each other and to reach out to their neighbours", or we shared Sinead Gleeson's hope "that we keep a candle lit in the window as reminder of all this passing darkness, and all the light ahead", or we admired Kevin Barry's contemplation of the power of Irish nature: "The Curlew mountains do not seem in any way perturbed, Lough Arrow remains serene, and the hills are the same old hills." Also, the death of Northern-Irish Derek Mahon left behind the beautiful line "the sun rises in spite of everything" from his poem "Everything is going to be alright", that has become a ceaseless expression of comfort this year. And likewise, the voice of Felicia Olusanya, Irish-Nigerian poet in a RTE's programme captured powerfully in "Still" the vibrant feeling of Ireland's restlessness and resolution during the lockdown. Just a few lines can be quoted to grasp her emotion: "For the Frontline workers armed with nothing but faith, / For the emerging minds that must dare to dream in high definition, / For the lonely minds that are glaring at love through a screen, / For the bodies that create homes in cardboard shelters. / Still. / For you. Ireland is standing still".

Our neighbours' work and artistry have been a lesson to bear isolation and anxiety, and have helped us to endure a life that depends now on charts and statistics, a new life for the living and the dead. And as we follow with preoccupation the development of this new and uncertain year, we look back at the 2020 looking for things that were done or those that were planned and have been postponed or cancelled and value all efforts and attempts. Before and after the declaration of the pandemic a trace of hard work shows that Irish studies in Spain have survived through this year.

Luckily enough, before the shutdown in March, the 5th International Seminar on Irish Studies - part of the EFACIS Irish Itinerary tour and with the support and collaboration of the Embassy of Ireland - was organized by the Granada Centre of Irish Studies at the University of Granada in February. The invited Irish writers were Donal Ryan and Emilie Pine who, with other prestigious keynote speakers and cultural activities such as performances by the Irish traditional music community in Granada and a workshop of "Céilí Dance", marked the beginning of this difficult year.

Many of the academic activities had to been cancelled or postponed but fortunately we will see most of them taking place during 2021. For example, the 19th International AEDEI Conference. Silences and Inconvenient Truths in Irish Culture and Society carefully planned and organized by Teresa Caneda at the University of Vigo will be a virtual event taking place online in May 2021 with guest speakers Professor Vincent J. Cheng (University of Utah) author of Amnesia and the Nation (Palgrave, 2018), Caelainn Hogan, writer and journalist, author of Republic of Shame: Stories from Ireland's Institutions for Fallen Women (Penguin, 2019); Mark Fitzpatrick (Yale University), director and producer of In the Name of Peace: John Hume in America, and poet Mary O'Malley poet and 2019 Writer Fellow at Trinity College Dublin (Gaudent Angel, Carcanet Press, 2019). Similarly, Shadows of Joyce in/and 
Irish Contemporary Authors, the International Conference of the James Joyce Spanish Association, organized by Juan Ignacio Oliva Cruz and his team at the University of La Laguna (Tenerife), was cancelled and has been postponed sine die to explore Joyce's role as a revolutionary, individualistic, and exiled writer. Also, AEDEI members will be able to attend the IASIL Symposium at the University of Łódź (Poland) as our colleague Ondřej Pilný announced its postponement to July 2021.

Unbeatable, the publication of the annual number of the review Estudios Irlandeses/Journal of Irish Studies came out triumphantly in March. All articles and contributions of this number 15 cover many issues on Irish productions. There are works on Brian O’Nalan, Joyce, Edgeworth, J.C Mangan, Brendan Behan, John MacGahern, Heaney, Kate O'Brien, Melusian Narrative, Eco and Beckett, Masculinities in Pub fiction, and Wilde. It also includes interviews with Eibhear Walshe and with the author Lillis Ó'Lahoire, and adds a section on "Reflections on an Irish American" and the translation and essay on Teresa Deevy's The King of Spain's Daughter. Somehow this publication symbolically put an end to the gloominess that the shutdown brought and blazed the path to many more projects that were to come during the year in spite of the adverse conditions. In fact, the publication of this number 15 was complemented later in the month of November when the special issue, number 15.2 saw the light. Edited by Margarita Estévez-Saá, Manuela Palacios-González and Noemí Pereira-Ares (University of Santiago de Compostela) and entitled Eco-Fictions, The Animal Trope and Irish Studies, it is a brilliant selection of high-quality articles which give a new insight into the many angles of Ecocriticism and fiction. These two last numbers of the review close the admiring work of the former general editor, José Francisco Fernandez and his team, formed by Verónica Membrive and Germán Asensio, who have been warmly congratulated for their outstanding work. The new editorial team led by Marisol Morales (University of Alcalá) as general editor with Asier Altuna-García de Salazar (University of Deusto) and Auxiliadora Pérez-Vides (University of Huelva) as managing editors will undoubtedly keep the quality standards of the journal.

April ended with the call for candidates for the new I Kate O'Brien Award organized by the Aula María Zambrano de Estudios Transatlánticos (AMZET) at the University of Málaga for works that study the relations between Ireland and Spain in the frame of literary and/or gender studies. Besides, the award ceremony for the II George Campell Award organized also by the AMZET was postponed to November. The prize was for Lorena Arce Romeral and Míriam Seghiri Domínguez (University of Málaga) for their work "Generación de plantillas de redacción y traducción (inglés-español) de contratos de compraventa de viviendas: un estudio aplicado a España e Irlanda" ("Generating templates for composing and translating (English-Spanish) contracts of sale: a study applied to Spain and Ireland"). There was also a secondary award (accessit) to "Relations Ireland and Spain, 1965 to present. An illustrated journey" by Martha Gutiérrez-Steinkamp, Smithsonian Fellow in the United States.

Also from La Rioja region good news arrived with the important publication of Trauma and Identity in Contemporary Irish Culture (Peter Lang Reimagining Ireland series, 2020), edited by Melania Terrazas (University of La Rioja). The highly-inspiring volume includes scholarly articles on Irish literature, film, digital archives, history and music, an unpublished essay by Irish artist Emer Martin, unpublished poems by Pat Boran, and an interview with the latter. Many AEDEI members have contributed to this enlightening piece of research whose beautifully designed cover is by Emer Martin.

St Patrick's Day in March is usually an important date regarding academic activities and other cultural events planned by AEDEI members. Unfortunately, the projects of the Irish Itinerary (EFACIS) organized by Banna/Bond, Center for Irish Studies at Deusto or La Rioja could not take place, but we hope that they will be planned again in the near future. Both events - Text, Music and Performance organized by Asier Altuna García de Salazar) and the 
III International Seminar on Saint Patrick's Day 2020 organized by Melania Terrazas counted on the participation of the Irish writer and artist Emer Martin and musician, actor and playwright Gerry Smyth (Liverpool John Moores University, United Kingdom). La Rioja had planned also a photograph contest "St. Patrick's Day y la cerveza Guinness en transformación", a lecture by Linda Connolly (Maynooth University) entitled "The Irish's Family", and a round table on Irish identity in transition. Similarly, the seminar Cultural Waves in Ireland and Irish Studies at the University of Huelva diligently planned by Auxiliadora Pérez Vides and José Carregal for April had to be cancelled. Also, the International Shaw Conference Shaw in Europe, co-sponsored by the International Shaw Society and the University of Extremadura, was to take place in May 2020. Its general topic is "Shaw and Europe" with special focus on the international dimension of the Irish author, especially Shaw's reception in Europe (ideas, works and translations). Luckily it has been postponed for 2021 and the dates will be announced on the ISS web page.

In June the new Executive Board of AEDEI was agreed upon in the General Assembly of the Association. Former President, Asier Altuna García de Salazar and his team received the warm gratitude of all members for their work and dedication and the new board was welcome: Pilar Villar-Argáiz (Chairperson), María Amor Barros del Río (Secretary), José Carregal (Treasurer) and board members Juan F. Elices and Melania Terrazas Gallego.

From June onwards, AEDEI members followed with interest the exciting new project launched by EFACIS as part of its Irish Itinerary Series: The Itinerary Podcast, which has proved an easy and useful tool to visualize the work of Irish artists and writers. Culture and academic work join together, letting us enjoy the online presentation of thought-provoking ideas, readings, performances, and conversations between creative minds and scholars. It has been a brilliant alternative to the traditional Irish Itinerary circuit in a digital version. From Spain, Irish Studies scholars as Pilar Villar-Argáiz and Marisol Morales-Ladrón participated in this transnational project hosting two interesting programmes. In September, Villar-Argaiz in Episode 5 talked to poet, translator and novelist Theo Dorgan and they discussed love poetry, Greek mythology, his translations of García Lorca, and the power of Irish language. Likewise, Morales-Ladrón in Episode 11 interviewed Irish-Canadian writer Emma Donoghue, discussing among many other topics women in Irish history and the author read fragments from her latest novel The Pull of the Stars (2020).

Many events commemorated a very different and unusual Bloomsday. At the University of Seville, Ricardo Navarrete and his team organized a special online Bloomsday event. Author of the clever article "Cómo perder el miedo a leer a Joyce/ How to lose the fear of reading Joyce" (The conversation.com, 2019), Navarrete organized the "Ciberbloomsday" with a documentary on Finnegan's Wake and a summary of the best moments of last year's XXX anniversary of the Spanish Association James Joyce, and the updates of the active webpage Iberjoyce, where every Sunday there is a commentary on a fragment of Finnegans Wake. Also the Zaragoza Bloomsday 2020: Entre el amor y la esperanza/ Between love and hope can be found in Youtube. It offered a mixture of music and literature with Celtic Airs, a group that has been for many years exploring the Celtic culture through music. Its members coordinated by Ana Hornero (Department of English Studies, University of Zaragoza), - also offered a special concert later in December, celebrating their special anniversary: 20 years of Celtic music in Spain (2000-2020).

Apart from all that, there has been a myriad of publications that show that 2020 has been a busy year in spite of the circumstances. From north to south, Spain proves the scholarly quality and variety of publications. From the dynamic group of scholars in Galicia a special monographic volume on Irish Studies in the journal Oceánide (vol. 13, 2020) was edited by María Jesús Lorenzo Modia et al. with many AEDEI members as contributors. Also David Clark Mitchell showed his expertise on crime fiction with an article in the volume Sins 
of the Fathers: Recent Crime Fiction and the Challenges of Policing a New Northern Ireland (Peter Lang, 2020), and with an a review of John Banville' The Secret Guests in ABEI Journal (2020). He has also contributed to important entries to the Dictionary of Literary Biography in the volume on $21^{\text {st }}$-century Irish Fiction (Farmington Hills/Gale, 2020) with writers such as Colin Bateman, John Boyne, or Liz Nugent, as Margarita Estévez has done likewise with Deirdre Madden. Luckily, Estévez has amplified her already vast research on Molly Bloom, analysing this character's representation in Joseph Strick's and Sean Walsh's films in her publication within the volume Page to Scree/Vom Buch Zum Film. Modification and Misrepresentation of Female Characters in Audiovisual Media (Narr Francke Attempto Verlag, 2020). Another interesting interdisciplinary contribution was the article on the Ulster Museum in Belfast by Antonio Río Vázquez (University of A Coruña) and Cecilia López Prego, a relevant architect in Galicia: "Preciso, ampliado, redibujado, recordado: Una revisión del proyecto de Pym y Lawson para el Ulster Museum" (VAD, vol. 2.1, 2020.)

New and very interesting titles came up in the volumes of the collection Studies in Irish Literature, Cinema and Culture (Edward Everett Root Publishers), coordinated by Pilar Villar-Argáiz, Kathryn Laing, and Sinéad Mooney. Among them, the thought-provoking volume by Constanza del Río and José Carregal (Revolutionary Ireland, 1916-2016: Historical Facts and Social Transformations Re-assessed, 2020), with contributions of some AEDEI members, discusses the concept of revolution in Ireland from different perspectives (history, sociology, film and literary studies). Also, in August, Gustavo Adolfo Rodríguez's chapter "Shaw's Ireland (and the Irish Shaw) in the International Press (1914-1925)" was included in the volume edited by Audrey McNamara and Nelson O'Ceallaigh Ritschel, Bernard Shaw and the Making of Modern Ireland (Palgrave Macmillan, 2020).

Many more publications can be found in the annual compilation that María Jesús Lorenzo Modia (University A Coruña) kindly and patiently puts together every year for the IASIL bibliography published in the Irish University Review. I also remain grateful to the three readers that have gently accepted to prove their expertise by reviewing the three works that follow.

\section{Works cited}

"For You. Ireland is standing still" The Irish Times, Friday October 2, 2020.

Higgins, Michael D. "Statement on the Death of Stephen Joyce" President of Ireland-Media Library, Friday, January 24, 2020.

“Irish Writers on Covid-19” The Irish Times, Saturday, March 28, 2020.

María Losada Friend is a senior lecturer in the English Department at the University of Huelva, presently teaching at the University Pablo de Olavide (Seville). Her main area of research is Comparative Literature and studies exchanges between Spanish, English, Irish and American narrative discourses, with published works on Oliver Goldsmith, James Joyce and Edna O'Brien. She co-edited Dreaming the Future: New Horizons/Old Barriers in 21stCentury Ireland (Irish Studies in Europe, vol. 3, 2011) and Words of Crisis/Crisis of Words: Ireland and the Representation of Critical Times (2016).

mlosfri@upo.es 
Alejandro O’Reilly, Inspector General: Poder Militar, Familia y Territorio en el Reinado de Carlos III

Óscar Recio Morales

Madrid: Sílex Ediciones, 2020. 516 pp.

ISBN: 978-84-7737-837-2

\section{Reviewer: Marta Ramón Garcia (University of Oviedo)}

Few tropes are as enduring in the Irish nationalist imagination as that of the Wild Geese: the waves of Irishmen who left their homeland between the sixteenth and eighteenth centuries in order to join the armies of European Catholic powers - mainly France and Spain - as the myth would have it, in search of military glory, religious freedom and an opportunity to return in force to liberate Ireland from British domination. Historical scrutiny, on the other hand, unsurprisingly reveals a more complex phenomenon: by the second half of the eighteenth century, the political exiles of the Tudor and Stuart wars had given way to economic migrants for whom Ireland was not so much a spiritual home, as a political badge and a business card to help them thrive in their host societies.

Óscar Recio Morales offers an enlightening case study in his impressively researched full-length biography of Alejandro (né Alexander) O'Reilly (1723-1794). Born as the eighth son of a minor County Meath landholder, O'Reilly was sent to Spain as a child along with two of his male siblings. He entered a career in the Spanish army at around the age of twelve, eventually found favour with Charles III, and rose through the ranks to become inspector general of infantry for the Spanish army, second governor of Spanish Louisiana, inspector general of the army and militia for Spanish territories in America, and military governor of Madrid by 1773 . Along the way, he had already been created a knight of the Order of Alcántara, commander of Benfayán (Cáceres), and finally Count O'Reilly in 1771. In 1776 he suffered a humiliating military defeat in Algiers and fell from grace, but the fall was tempered by his appointment as captain general of Andalucía, and later governor of Cádiz. He resigned from all his commissions in 1786, was called back from retirement for the war against the French revolutionaries in 1793, and died en route to the front in Bonete, Albacete, on 23 March 1794.

Aside from its intrinsic scholarly merit, the value of Recio's biography of O'Reilly is twofold. First, it fills a significant gap in the historiography of the Spanish Enlightenment; despite O'Reilly's prominence in Charles III's military establishment, he tends to be absent from general accounts of the period, and only his brief stint as Louisiana governor seems to have attracted attention, mainly on the part of North American scholars (12). Secondly, it adds more particularly to the historiography of the Irish diaspora in Spain. While there is a relative abundance of articles on the Irish in early modern Spain, with topics ranging in scope from individual case studies, to local histories, to collective analyses of religious and political activities (e.g. Pérez Tostado and Downey eds., 2020), there is a glaring dearth of monographs able to engage with the Irish émigré experience beyond the confines of the tenthousand-word limit.

For the Spanish history reader, Recio offers a succinct but informative summary of the Irish context for O'Reilly's exit from Ireland, from the Williamite War and the Penal Laws, to the several famines of the early eighteenth century. He does this with a notable lack of wildgoose romanticism, more instructively focusing on the lack of opportunities for Catholic families, the role of familial networks and the continuity factor involved in leaving one strongly militarised society for another. He also provides a striking counterpoint to the historical reputation of King Charles III. Usually hailed as the quintessential enlightened monarch, the patron of arts and rational government, "the best mayor of Madrid", behind 
some of the most iconic Madrid architecture, from the Prado Museum to the Alcalá Gate, Recio's Charles III instead emerges as a militarist who involved the country in ill-fated ventures, financed his urban improvement schemes by over-taxing an impoverished populace, and fled the capital for a full nine months when said populace revolted against his reforms in 1766.

But perhaps the most damning portrait in Recio's narrative is that of the Spanish ancient-regime aristocratic class. O'Reilly's career as inspector general of infantry was a sustained attempt to modernise and professionalise the Spanish army by emphasising formal instruction, limiting the purchase of military commissions, reducing endogamy and introducing a promotions system based on excellence rather than perceived hereditary rights. But this was a direct challenge to the aristocracy's monopoly over the upper military echelons, and their response is both predictable and at times unintentionally funny. O'Reilly's efforts culminated in the foundation of a short-lived military school at Ávila (1774-1779); he intended that the most promising officers in each regiment should attend this school, and that their performance should be a deciding factor in future promotions. Unsigned reports originating from the office of War Secretary Count Ricla, his superior, protested that this gave O'Reilly inordinate power - his school, his exams, his officials - shattered the principle of seniority, and led to veteran officers finding themselves under the command of newcomers, sometimes of "vulgar" origins (246). O'Reilly was not simply disregarding the true virtues of "blood, valour and seniority"; his educational programme was unnecessarily taxing for the students, and his insistence on "excessive hygiene" bordered on effeminacy and went radically against the "national character" (247).

This was the inspector's fundamental flaw in a society obsessed with "purity of blood" and "old Castilian" credentials: his novel title as Count O'Reilly and his foreign origins disqualified him from truly comprehending the "spirit of the nation" (252). In the aftermath of the Algiers disaster, O'Reilly was classed with other foreign officials elevated by Charles III, such as the unfortunate Esquilache, and his origins were made the target of literary attacks, very likely orchestrated by his enemies among the nobility (320-25). Recio quotes abundantly from this satiric output, and places it in the context of the emergence of a Spanish "protonationalism" which looked to popular culture, particularly that of the Madrid lower classes, as the embodiment of the "national spirit" that O'Reilly supposedly could never commune with.

It is precisely in defining the contours of his Hispano-Irish identity that O'Reilly benefits from the full scope of a biography. Recio begins by lamenting the lack of a personal autobiography to balance the reams of paperwork produced by O'Reilly in his professional capacity, and declares that he has tried to avoid presenting him as a mere bureaucrat (20). While there is no lack of bureaucracy - to a degree of detail that makes footnotes as often interesting as overwhelming - Recio succeeds in building a personal portrait of a man he describes as "controversial", but who mainly comes across as an extremely talented, meticulous, efficient reformer with a superhuman capacity for work, and an all-too-human array of contradictions.

It is particularly remarkable, for instance, that for such an assiduous opponent of the aristocratic oligarchy in the army, he did not abstain from recommending candidates on the basis of family origins or connections, and he was far from immune himself either to social ambition or clientelism. As early as 1758 he was already sounding out his superiors about the possibility of being conferred with a nobility title (56). A few years later, in 1767, his marriage to María Rosa de las Casas y Aragorri connected him with the powerful Basque faction at court, and the children born of the marriage solidified his Spanish roots. Meanwhile, his rise to prominence was assisted as much by his personal competence as by the influence of benefactors of Irish origins, notably Secretary of State and War Ricardo Wall 
(1694-1777), who promoted his appointment as military observer to Central European armies during the Seven Years' War and brought him to the attention of Charles III.

As the all-powerful inspector general of infantry, O'Reilly would secure promotions for his own family members (64-5), and take other Irish protégées under his wing, especially his own cousin Hugo O'Conor and Gonzalo O'Farrill y Herrera, a member of the Cuban upper class who embodied one of O'Reilly's most successful projects: the promotion of the military as a desirable career for colonial elites, as a means to reinforce both the defence of their respective territories and their own allegiance to the metropolis. O'Farrill would occupy various prominent military positions in Spain, including inspector general of infantry in 1798, before eventually accepting the post of secretary of war in Joseph I Bonaparte's government and being forced into exile at the end of the Peninsular War (1808-1814).

Recio, on the other hand, is not concerned with building a map of Irish connections. He does provide a brief insight into the endogamic Irish regiments in the Spanish army (58-9) and the Irish community in Cádiz (348-9), and Irish individuals do occasionally feature in the narrative as O'Reilly's collaborators and confidants, as is the case of Thomas Butler in Havana and Oliver Pollock in Louisiana. However, the intricacies of blood and political allegiances untangled for the reader are mainly those of the Basque and Cuban elites O'Reilly came in contact with, and the different factions in Charles III's governments.

Recio's O'Reilly is certainly not the nostalgic emigrant of Irish nationalist imagination. In 1735 O'Reilly was sent to Spain on a calculated move to provide him with a career as an officer in the Spanish army through enlistment as a cadet in the Hibernia regiment, one of three Irish regiments in the Bourbon "army of nations" (57). Recio describes this environment as a "bubble", thus suggesting that young O'Reilly's contact with Spanish culture and society may have been limited during his formative years. At the same time, however, there is no mention of return trips or significant contacts with the family he had left behind. From the moment he became a cadet, up to his final retirement in 1786, O'Reilly's interests and ambitions materialised exclusively within the confines of the Spanish state. Unlike his compatriot and benefactor Ricardo Wall, who served as ambassador in London and was a declared Anglophile, O'Reilly manifested no particular affinity or aversion to Britain beyond his military duty to defend Spain from a colonial adversary. Most telling of all, unlike Wall, who made repeated protestations about his loyalty to Spain, O'Reilly never felt the need to do so, and he never questioned his own identity as a Spaniard.

Recio emphasises that O'Reilly's deployment of his Irish identity was eminently pragmatic: it served him to gather witnesses for his application to the Order of Alcántara, and later to try and produce a sufficiently impressive family tree to obtain a title of grandee for his son and heir (322-3). However, his exit from the Hibernia regiment, his experience as a military observer in Central Europe, his interest in French military literature, his missions in Cuba and Louisiana, and his Basque connections, all added new identities to the mix.

This is perhaps the most important takeaway from Recio's work. Identity is multifaceted, and a reader looking for the "Irish experience" will find a much richer kaleidoscope: an extremely talented, resolute, ambitious career official, who shared the values of elite society, and as a slave owner himself, some of its very worst practices; also an efficient and dedicated reformer who failed to modernise the army according to his vision, but managed to leave a durable imprint as the governor of Cádiz. As a backdrop, the book offers a fascinating window into the rivalries and intrigues at Charles III's court, a minutely detailed account of the workings of the Spanish army, and a glimpse into the forces at work in Spain's long descent into decadence and civil strife throughout the nineteenth and early twentieth centuries. It is only to be lamented that the book is inaccessible to an English-language audience, but it is to be hoped that translations, in whole or in part, will soon be forthcoming. 


\section{Works cited}

Pérez Tostado, Igor and Declan M. Downey, eds. Ireland and the Iberian Atlantic. Migration, Military and Material Culture. Valencia: Albatros, 2020.

Marta Ramón García is a lecturer at the Department of English, French and German Philology at the University of Oviedo (Spain). Her primary field of expertise is nineteenthcentury Irish nationalism, and her main full-length publications are A Provisional Dictator: James Stephens and the Fenian Movement (UCD Press, 2007), and the edition of James Fintan Lalor's writings The Faith of a Felon and Other Writings (UCD Press, 2012). Her current research interests include "rational recreation", health and civic culture in nineteenthcentury Ireland.

ramonmarta@uniovi.es

\section{El relato corto: Sean O'Faolain}

Edited by José Francisco Fernández and translated by Leticia de la Paz de Dios Almería: Editorial Universidad de Almería, 2020. 288 pp.

ISBN: 978-84-17261-71-9

Reviewer: Santiago Rodríguez Guerrero-Strachan (University of Valladolid)

Sean O'Faolain, the penname of John Francis Whelan (1900-1991), is one of the three writers who set the standard for the Irish short story in the twentieth century, along with James Joyce and George Moore. It is no coincidence that both O'Faolain and Frank O'Connor wrote two essays on the short story, The Short Story (1948) and The Lonely Voice (1962), respectively, since both writers felt the need to define the genre and to offer some reasons for its popularity. O'Faolain, an editor himself, also published several essays on the genre in The Bell in 1944, under the title "The Craft of the Short Story", and these form the basis for the current book. As an editor and a practitioner of the genre, O'Faolain did not establish fixed rules for new writers, preferring to analyse various authors and provide his own opinions as to what makes a short story great.

The book opens with a brief introduction in which he stresses the importance of technique and the author's personality, followed by three broad sections, each containing several chapters, that deal with the necessity of literature, a detailed analysis of the short fiction of Alphonse Daudet, Anton Chejov and Guy de Maupassant, and an exploration of the narrative techniques of the genre.

The first section is a preliminary one, and in it O'Faolain sets out the scope of his endeavour. The book is intended to help new authors in their careers, and here the tone and structure of the book is explained. It begins by asking rhetorically why people feel the urge to write and continues with a warning to such would-be writers about the hardships that they will probably face throughout their lives. He goes on to deal with one of the central topics of the book: a good work of literature must balance the author's personality and the circumstances in which it has been written. In O'Faolain's opinion, no piece of narrative can be successful if it is not born of the writer's own experience. Life nurtures literature, he argues, with the technical aspects of literature relegated to a secondary level.

He briefly discusses English, Irish and American fiction, concluding that English insularity has resulted in a kind of short fiction that is inferior to that being written by Irish 
and American authors, this largely a consequence of the English derision for the artistic personality. The English have fine novelists because their lives are centred in society, while the Irish tend to be rather unconventional, which in turn results in good short stories.

In the second section of the book, the author discusses the personal struggles involved in writing short fiction, looking at three authors who are not Irish. While there is little doubt that Chejov and Maupassant are masters of the short form, Daudet may come as a surprise to the reader, who may wonder whether O'Faolain's poetics of realism led to a biased selection here. O'Faolain discusses the French author's work in terms of one of the most important aspects of short fiction: the centrality of characters, to which he adds the role of a poetics of Realism.

It is this poetics of Realism that drives the second section. The three writers are examples of Realist fiction, and O'Faolain explores the particularities of each author. While Daudet is true realist, focusing as he does on tiny aspects of life, Chejov is the supreme master of suggestion. He writes about common people, often creating archetypal characters, and showing sympathy towards these while keeping himself at some distance as a writer. His gaze is detached and objective, and he never seeks to romanticize the lives of his characters. O'Faolain provides a detailed analysis of how suggestion works in Chejov's stories and how the external world is subordinated to the creation of an atmosphere or an impression, one which is most often poetic. He was a realist sui generis, what we might now term an impressionist.

Finally, Maupassant is described as being the least influenced by literature, an author who developed as a writer capable of simply observing the life around him and making from this a story. As a realist he simply observes and reports. He does not sermonize or condemn his characters' actions. In a similar way to Chejov, he strips the story of everything that is not essential, and his stories thus serve as an indication of the path that the short story would follow in the twentieth century with James Joyce and Ernest Hemingway.

The third section is devoted to technical aspects of the genre in what is a somewhat rambling exposition. O'Faolain's belief in the unteachability of writing leads him to argue that it makes no sense to teach the narrative strategies that the author might use when writing short fiction. Rather, he discusses narrative conventions, and gives copious examples to illustrate the various points he makes. He does not rely in this section on the authors whose work he had previously explored, turning instead to writers like Elizabeth Bowen and Henry James. He acknowledges that there are two important conventions at play: to start the story without a preamble, and to use the art of suggestion when providing the reader with information. However, O'Faolain is aware that the short story is a convention in itself, since it does not deal with a whole life but with pieces of that life that have been carefully selected. For the Irish author, the openings and the closures are since the short story is a condensed type of narrative. However, he never mentions Poe as one of the initiators of the modern short story, a writer who put the emphasis - albeit indirectly - on the importance of openings and closures, as is clear from a story like "The Black Cat". In the first paragraphs here, Poe provides information as to the type of narrative which will follow. Indeed, a great deal of recent research into short fiction has focused on closures. Similarly, O'Faolain's notion of the short story as a fragment of life retains its relevance if we consider Raymond Carver and Alice Munro's short fiction; different as their narratives are, they both take the form to constitute the description of a slice of life.

In any case, and despite O'Faolain's insistence in the author's personality when writing a story, he explores aspects such as point of view, topic, structure, and language itself, which is obviously more condensed than in a novel. He favours intensity and uniqueness, this a consequence of the kind of suggestive narrative he argues for, as well as the centrality of the 
author's personality. O'Faolain started writing in the period after Joyce had published Dubliners, which explains his explorations of the limits of Realism and Naturalism.

The edition has been prepared by José Francisco Fernández Sánchez, a specialist in the Irish short story. His introduction provides the biographical and historical contexts in which O'Faolain wrote. It is brief, intense and personal, thus reflecting the tone of work itself, which has been beautifully and accurately translated by Leticia de la Paz de Dios. I would only point to the translation of "short story" ("relato corto") and suggest that it might have been replaced with "relato breve", since "corto" refers to length and "breve" to duration, and Poe argued that the brevity he referred to when writing about the short story was that of duration. I would also suggest that we might all make use of other Spanish terms when translating, such as "cuento literario" or "cuento modern", the type of short fiction that Poe, Nathaniel Hawthorne and Nicolai Gogol initiated in the nineteenth century as different from the traditional tale. In any case, these are minor suggestions for a translation which is accurate, has a fluent feel, and is thankfully free of typographical blemishes.

The Short Story may seem a piece of historical criticism with little contemporary interest for some readers. This is far from the truth. It is a book that can indeed appeal to young authors and readers, as well as to scholars and critics. O'Faolain's opinions on the short story, and his analysis of both authors and specific stories, shed valuable light to a genre which, despite being scarcely 200 years old, has already led to a variety of masterpieces.

Santiago Rodríguez Guerrero-Strachan is Senior Lecturer at the University of Valladolid (Spain). He teaches American Literature. His research focuses on the reception of literature written in English in Spain (E. A. Poe, T.S. Eliot, P.B. Shelley) and American short fiction (E.A. Poe, N. Hawthorne, H. Melville, R. Carver, R. Ford, S. Dybek, among others). He has published Presencia de Edgar Allan Poe en la literatura española (1999), En torno a los márgenes: Ensayos de literatura poscolonial (2008), has edited Antología del cuento grotesco (2007) and Pioneros. Cuentos norteamericanos del siglo XIX (2011) and translated and edited some Henry James' short fiction (2005). He has also translated Walt Whitman's Specimen Days (2019).

guerrero@,fyl.uva.es

\author{
Samuel Beckett en España: A Multifaceted Perspective \\ José Francisco Fernández (ed.) \\ Valladolid: Universidad de Valladolid, 2020. 230 pp. \\ ISBN: 8413200857
}

Reviewer: Jordi Vilaró (Universitat Oberta de Catalunya)

Raquel Marino states that, traditionally, reviews of the history of Spanish theatre within academic research have focused on productions of Spanish playwrights and paid insufficient attention to translations and performances of works by foreign authors. Marino even talks about the marginalisation of translated theatre, above all with regard to those foreign authors whose plays were premiered during Franco's dictatorship: 
A pesar de que la producción dramática traducida ha sido siempre una parte importante de nuestro teatro, se trata de una sección de la historia teatral de nuestro país tradicionalmente relegada. Y es que podríamos afirmar que la historia del teatro en España se ha escrito pensando en la producción nativa de dramaturgos españoles, como si el nuestro (o cualquier otro teatro) existiera sólo en versión original. Por razones de diversa índole, pero sobre todo por tradición académica, el teatro traducido se ha visto postergado. (358)

Nevertheless, in recent decades a number of doctoral theses and studies have adopted a new approach to foreign theatre translated and performed in Spain. These studies have not only enriched our vision of the foreign author but also enabled us to understand an essential part of the history of our own theatre. Without any doubt whatsoever, the current book, edited by José Francisco Fernández, makes a great contribution in enriching this kind of research.

Samuel Beckett en España presents a very interesting and multifaceted appraisal of the reception of Samuel Beckett's works in Spain, from the time his plays were premiered to recent theatrical productions.

The book opens with an article by one of the most renowned specialists on the work of Samuel Beckett in our country, Antonia Rodríguez-Gago. In her article "Beckett transcultural y los 'clásicos' españoles de Winnie", Rodríguez-Gago explains the importance of transculturality in Beckett's plays. According to her, the role of the culture of a specific country in the translation of Beckett's plays is fundamental, even more if we consider that he is an author who wrote using two different languages: English and French. He also directed some of his plays in both languages, adapting them to the culture of each country where the plays were performed. Rodríguez-Gago takes as an interesting example of transculturality the creative process in the staging of Happy Days by the Spanish theatre company El Canto de la Cabra in Madrid in 1996.

According to Manuel García Martínez's "La recepción de las obras de Samuel Beckett en Galicia", Beckett's plays were performed in Galicia by university theatre groups during the 1960s. These performances were in Spanish since there were no Galician translations of Beckett's plays until 1976 (Acto sin verbas) and his plays were not performed in Galician until 1982. For García Martínez, the lack of interest in Beckett's plays in Galicia was due to the philosophical content of his plays and the lack of political commitment of his theatre. The European opening of A Piece of Monologue in Spain at the University of Santiago de Compostela in 1982, which was made possible by the enthusiasm of two English teachers at the university (Manuel Carreira and David Green), deserves specific mention and is one of the most curious and remarkable parts of García Martínez's article.

In "La introducción de Beckett en los escenarios catalanes", Núria Santamaría also explores in depth the reception of Samuel Beckett's plays in Catalonia. She states that the first performances of Beckett's plays in Barcelona were by "compañías de Teatro de Cámara" (studio theatre companies) from Madrid and that it was not until the end of the 1950s that there was a Catalan translation of a Samuel Beckett play: En attendant Godot (Tot esperant Godot). However, this play was not performed until the end of the 1960s by amateur groups, with no relevant repercussions. The debate over Beckett's plays between artists and intellectuals in Catalonia was not too different from that in Galicia: in Catalonia the plays were seen as dark and intellectual, without a clear political commitment. Theatre engagé was considered important among independent theatre groups in order to make a difference in comparison with the conventionality and conservatism of official and commercial theatres. This debate increased after Samuel Beckett received the Nobel Prize in 1969 and more voices were raised to situate Beckett at the centre of any theatrical canon. However, there was a problem - as was also the case in Galicia - in that there was not a ready audience for 
Beckett's work. As Joseph Maria Flotats pointed out in his conversation with Baltasar Porcel: "El país no está preparado para cosas difíciles" (9). It was thanks to the efforts of certain theatrical groups, such as La Gàbia Teatre, that the flame of Samuel Beckett's plays was kept alive during that time. In the second part of the article, Santamaría carefully examines the role of this independent group, led by Joan Anguera, in performing Samuel Beckett's work in Catalonia. When La Gàbia Teatre turned professional in 1979, as Santamaría states, "ya nadie discutía la conveniencia de ofrecerlo [a Beckett] en catalán en teatros convencionales como sucedía en las culturas contiguas".

In "La censura del teatro de Samuel Beckett en España (1955-1978)", Olaia AndaluzPinedo and Raquel Merino-Álvarez offer a careful analysis of censorship of Samuel Beckett's plays in Spain during the Franco period. The exhaustive research by these authors on the censorship files located in AGA (Archivo General de la Administración) reveals how Beckett was seen by his censors mostly as a vanguardist and as a polemical and incomprehensible author. Thus, his plays were classified as "aptas para minorías" and the censors allowed their performance in Teatros de Cámara. Most of his plays, though, had no special problems with the censors, an exception being La última cinta de Krapp. Objections to this play were raised because of "morbosidades sexuales, juramentos, extravagancias y anomalías", according to the censor Rev. Esteban Romero. Andaluz and Merino also point out the importance of Trino Martínez Trives as the main diffuser of Samuel Beckett's work in Spain.

In "Las traducciones de Esperando a Godot en España", David Martel analyses the four existing Spanish translations of Esperando a Godot and points out that all of them derive from the same original source: the French version of 1953. Therefore, none of these translations is $100 \%$ identical to Beckett's definitive version of 1970 . The conclusion that Martel reaches after studying the four translations (by Pablo Palant, Trino Martínez Trives, Pedro Barceló and Ana María Moix) is that they are not faithful to the original; some of them are quite inaccurate (such as the last one by Ana María Moix) and none contains a critical edition with footnotes or prologue that explains to the reader the meaning of the dramatic action.

As a perfect complement to this article, Carlos Gerald Prager's "Samuel Beckett, un mal viaje por España: recorrido por las versiones del Godot" also criticises the lack of good Spanish translations of En attendant Godot (Esperando a Godot). He focuses attention on the inexplicable absence of translations of the English version of the play (Waiting for Godot), which Samuel Beckett himself translated in 1970. Gerald Pranger considers that any translation brings new meanings to the original text (transcodification). Moreover, having translations of only one version of a play such as En attendant Godot means renouncing intertextuality and interdiscursivity, especially in a work conceived to be performed. He also criticises the lack of serious studies of the work of Samuel Beckett and provides interesting reasons for this: under Francoism the political commitment of Beckett to the Spanish Republic (and his support for Fernando Arrabal), inaccurate translations and the labelling of his theatre as "absurd", existentialist or metaphysical, in contrast to the social realism of Bertolt Brecht, who was much more widely accepted among Spanish intellectuals for many years.

The editor of this book, José Francisco Fernández, provides the only reception study of Samuel Beckett not linked to a theatrical work. In "Aquí donde reina la justicia': La recepción de Cómo es de Samuel Beckett", Fernández focuses on the reception of Samuel Beckett's novel Comment c'est (Cómo es) in 1961 and reaches the conclusion that this novel can be added to the list of "insufficiently explored" works of the Irish author in Spain. His article is divided into two parts: first, he exposes and comments on the several translations of this novel into Spanish, and second, he analyses the novel itself and its particular "oddity" according to the Spanish values system and how the novel helped to break these values, 
mainly during the Franco period. This would have been one of the reasons for the "discreet" reception of this work.

Loreto Casado, in "Beckett, Lucky y Deleuze", returns to Carlos Gerald Pranger's criticism of the lack of interest in deeply exploring Beckett's work in Spain. Casado explores the philosophical background to Beckett's work, with highlights such as the physical universe beyond the words of his characters. Casado finds that the exploration of the concept of "desterritorialización", which according to Gilles Deleuze defines the literature of Franz Kafka, is also applicable to Beckett's plays.

Finally, the book closes with two valuable and exhaustive articles by Mar Garre García about all the academic publications and articles on the works of Samuel Beckett in Spain.

As we can see on the various articles in this comprehensive book, the reception of Samuel Beckett's work in Spain has been irregular, primarily for the following reasons: some suboptimal translations, the lack of a theatrical tradition in some regions (or disruption of a tradition by Francoism), censorship during the dictatorship and a Spanish audience split between the escapist/commercial options on the one hand, and so-called committed theatre, on the other. However, the eclecticism of the 21 st century has offered new perspectives and possibilities for the different themes and forms of a theatre so rich and multifaceted as that of Samuel Beckett.

Talking about the theatre of this author, Ricard Salvat said "la paraula en Beckett és un camí cap al silenci" (44). Playing with this statement, we can say that this "silence" on stage has accompanied Beckett's works in Spain for a long time. Fortunately, the interest in the author and the studies that his works generates are now no longer a "path toward silence", as this book brilliantly shows.

\section{Works cited}

Merino Álvarez, Raquel. "La historia de las traducciones de teatro inglés en España en el siglo XX: perspectiva desde el proyecto TRACE." Lengua, traducción, recepción: en honor de Julio César Santoyo. Ed. Rosa Rabadán, Trinidad Guzmán and Marisa Fernández. León: Universidad de León, Área de Publicaciones, 2010, 357-84.

Porcel, Baltasar. “Josep Maria Flotats 'comedien’”. Destino, 1717 (29 agosto 1970).

Salvat, Ricard. El teatre contemporani. Vol 2. Barcelona: Edicions 62, 1966.

Jordi Vilaró Berdusan is BA in Catalan Philology at the Universitat de Barcelona (UB), MA in Theory of Theatre and Critique and PHD in Theatre Studies (International Doctoral Research Component) both at the Universitat Autònoma de Barcelona (UAB). He is currently working as Assistant Professor at the Universitat Oberta de Catalunya (UOC) and his main research interest is the reception and influence of Anglo-Saxon playwrights in Catalonia. $\mathrm{He}$ is member of the Grup d'Estudis de Literatura Catalana Contemporània, an academic research group focused on contemporary Catalan literature, and he has published several articles, prologues and reviews. He is about to publish his first essay book: L'amabilitat dels desconeguts (Institut del Teatre, 2021), a study about the reception of the plays of Tennessee Williams in Barcelona during the Francoism.

jvilarobe@uoc.edu 